\title{
Editorial Editorial
}

GALILEU - REVISTA DE DIREITO E ECONOMIA - e-ISSN 2184-1845

Volume XXI $\cdot 1^{\text {st }}$ July Julho $-31^{\text {st }}$ December Dezembro $2020 \cdot$ pp. 6

DOI: https://doi.org/10.26619/2184-1845.XXI.2.1.1

Continuamos a nossa caminhada com a apresentação deste novo número onde permanecemos fiéis à apresentação de trabalhos de investigação provenientes de investigadores de diversas origens e graus, resultando esta pluralidade da seleção dos trabalhos mais atuais e pertinentes no atual panorama jurídico.

Agradecemos todos os contributos dos autores cujos trabalhos são alvo da presente publicação, estendendo um novo convite a todos aqueles que queiram contribuir com os seus trabalhos, originais, inéditos e relevantes, nos próximos números da revista Galileu.

O contexto de pandemia imperante nos últimos tempos tem avalado muitos ânimos, mas congratulamo-nos por verificar que não gerou desídia na comunidade científica, que continua a desenvolver trabalhos de investigação tao interessantes e pertinentes como os que ora se publicam.

Um muito obrigado para todos os nossos colaboradores e um bem hajam para os leitores!

O Diretor da Galileu

Ruben Bahamonde Delgado 